\title{
EVIDENCE "NOT IN A FORM FAMILIAR TO COMMON LAw COURTS": ASSESSING ORAL HISTORIES IN LAND Claims Testimony After DelgamuUkW v. B.C.
}

\author{
ANDIE DIANE PALMER
}

The Supreme Court of Canada's recent decision in Delgamuukw $v$. B.C. permits a reconsideration of the place of oral traditions in aboriginal land claims cases. The Court advises that oral histories be given "independent weight," and that at trial McEachern C.J. had not "assessed the oral histories correctly." However, the Supreme Court of Canada's view of how to weigh oral history in testimony is troublesome, in that then-Chief Justice Lamer informs us that such key features of oral histories as "moral obligations" are "tangential to the ultimate purpose of the fact-finding process at trial - the determination of the historical truth." This article considers how courts will be able to evaluate oral histories in the future. if such key features of testimony are 10 be discarded.
La décision que la Cour suprême du Canada vient de rendre dans l'affaire Delgamuukw $c$. la ColombieBritannique nous permet de réexaminer la place qu'occupent les traditions orales dans les revendications territoriales des Autochtones. La Cour demande qu'on accorde "un poids indépendant " aux histoires orales et qu'au procès, le juge en chef McEachern " $n$ 'avait pas évalué les histoires orales correctement". Cependant, la façon de la Cour suprème du Canada de pondérer les histoires orales dans les témoignages est source de complications en ce sens que Lamer, juge en chef à ce moment-là, nous informe que ces éléments clés des histoires orales en tant "qu'obligations morales " sont "tangentielles "dans le but ultime du processus de l'établissement des faits pendant le procès, soit l'établissement de la vérité historique. L'auteur de cet article se penche sur la façon que les tribunaux devront évaluer les histoires orales à l'avenir si de tels éléments clés de témoignages doivent ètre écartés.

\section{TABLE OF CONTENTS}

I. INTRODUCTION . . . . . . . . . . . . . . . . 1041

II. PRoblems WITH THE APPLICATION OF THE VAN DER PEET

PRINCIPLES TO THE DELGAMUUKW CASE . . . . . . . . . . . 1041

A. What'S IN A NAME?: DifFERENT CULTURAL

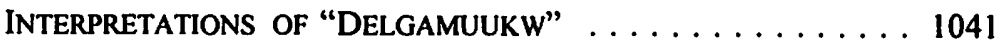

B. How ORAL Histories aRE to BE WeIGHTED . . . . . . . . . 1044

C. ON HEARSAY: MCEACHERN C.J.'S ATTEMPT TO

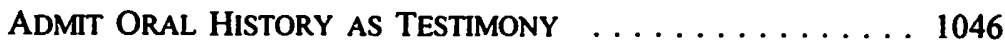

D. THE ROLE OF ANTHROPOLOGISTS:

THE Place of Judicial Notice . . . . . . . . . . . . . . 1047

III. CONTRASTING NOTIONS OF TITLE AND SOVEREIGNTY:

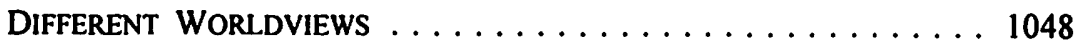

IV. THE LARGER ISSUE $\ldots \ldots \ldots \ldots \ldots \ldots \ldots \ldots \ldots \ldots$

Assistant Professor, Department of Anthropology, University of Alberta. I am most grateful for the comments and helpful suggestions of an anonymous reviewer for the Alberla Law Review, and Claire Klassen, LL.B. Franca Boag and fellow members of my writer's group, Julie Rak, Aara Suksi, Cecily Devereaux, and Heather Young Leslie also receive thanks for their encouragement and for patient readings of earlier drafts. Aaron Palmer, LL.B., and Carl Urion were extremely helpful in their discussions of an earlier version, presented at the Canadian Anthropological Society meetings at the University of Toronto in 1998. Any errors are, of course, my own. 


\section{INTRODUCTION}

The Supreme Court of Canada decision in Delgamuukw v. B.C.' has been touted as holding promise for the future consideration of oral histories as evidence in Aboriginal land claim cases. The purpose of this article is to make it evident that no advancement has yet been made in the Supreme Court of Canada's instructions for the interpretation of oral histories offered as testimony by Aboriginal Peoples. I argue that we have been instructed that oral history be given weight as part of land claims testimony, but have yet to produce the scale that could properly do so. I will examine Lamer C.J.C.'s (as he then was) instructions for the weighing of oral histories, and will also consider MacEachern C.J.'s attempts to give consideration to oral histories. The latter will be done in order to demonstrate how even the application of the principles laid out in $R$. v. Van der Peet ${ }^{2}$ could not have assisted McEachern C.J. in his interpretation.

I will argue that Lamer C.J.C.'s instructions in the Van der Peet decision do not provide sufficient direction to account for the ways in which either the content or the anthropological interpretation of oral histories contribute to his decision in the Delgamuukw case. I will discuss some reasons that expectations for a different assessment of oral histories than McEachern C.J. offered might not be forthcoming in a new trial. What Lamer C.J.C. proposed (that oral histories be given weight) is an ideal. What he in fact delivered, with the application of the principles laid out in the Van der Peet decision, is a temporary remedy resulting from the lack of shared understanding between the appellants and the judiciary of the direct referents and social meanings of the presented oral histories. Lamer C.J.C.'s separation of oral histories from the "moral obligations"' these entail is indicative of this lack of understanding. This article, informed by Clay McLeod's discussion of judicial notice, ${ }^{4}$ proposes a partial remedy for this dilemma. I will conclude by considering an alternative judicial framework to that currently used by Canadian courts.

\section{Problems with the application of the Van der Peet Principles to the DelgamuUKW CaSe}

\section{A. What'S in a Name?: Different Cultural INTERPRETATIONS OF "DELGAMUUKW"}

Contextualization of oral histories, and reasoned explications of associated social meanings, are essential to the interpretation of oral histories presented by Aboriginal witnesses. Shared terminology does not necessarily correspond to shared meanings of terms across cultures. In order to explain some of the fundamental differences in terminology which may have a bearing on the interpretation of law, I begin with an

[1997] 3 S.C.R. 1010 [hereinafter the Delgamuukw case].

R. v. Van der Peet, [1996] 2 S.C.R. 507 [hereinafter Van der Peet].

Supra note 1 at para. 86.

C. McLeod, "The Oral Histories of Canada's Northern People, Anglo-Canadian Evidence Law and Canada's Fiduciary Duty to First Nations: Breaking Down the Barriers of the Past" (1992) 30 Alta.

L. Rev. 1276. 
example from the decision of the Delgamuukw case: the social meanings and uses of the name "Delgamuukw" as used by the members of two different cultures present during that case.

This example is concerned with the extension of the Euro-Canadian legal custom of using a name to stand for a citation of a case (e.g., Guerin, for Guerin v. The Queen ${ }^{5}$ ) to include the use of Northwest Coast First Nations' chiefly names for this purpose. My discomfort with this practice is engendered by my long consideration of the use of such names by speakers of the Coast Salish language, Lushootseed. According to my fieldwork experience as a linguistic anthropologist, a Lushootseed chiefly name should be spoken when formally calling on someone to respond to a request. This includes asking them to speak or to bear witness at a longhouse event or other public gathering. When referring to someone in passing in conversation, the uses of kin terms and other circumlocutions may be more properly employed.

The use of "Delgamuukw" as a reference to a whole court case, rather than to a particular wearer of a name and/or to once and future wearers of that name, is potentially unmindful of its normal use as a chiefly name, and of its place of use in another legal system. Chiefly names, as used on the Northwest Coast, are the property of clans and other kin groups, and are formally transferred between members of one lineage in the presence of invited witnesses from other lineages. Witnesses signal their acknowledgement of the rightful ownership of a chiefly name through their attendance at a ceremonial feast to mark that transfer, and through their acceptance of thanks in the form of food and other gifts distributed at the ceremony. To use a chiefly name in the address of an individual in ceremony, then, is to acknowledge that the addressee is the rightful bearer of that chiefly name, and of the property (including land, crests, and stories) that is transferred with it. In four publications (including three publications over which Gitksan and Wet'suwet'en organizations hold copyright), "Delgamuukw" is referred to by Gitksan and Wet'suwet'en writers as: "[T]he Gitksan and Wet'suwet'en Sovereignty Case," as "this case," and as "the claim." When the chiefly name is used in reference to the Delgamuukw case, it is only used by these writers in larger phrases as "the Delgamuukw case" and "the Delgamuukw court case." I will follow the example of these writers, who have an understanding of the appropriate uses of such names in their feast systems.

It should become apparent, then, that even in the apparently minor details of language use, the shortening of a case name according to the custom of one group (in this instance,

S Guerin v. The Queen. [1984] 2 S.C.R. 335.

- D. Monet \& Skanu'u (A. Wilson), Colonialism on Trial: Indigenous Land Rights and the Gitksan and Wet'suwet'en Sovereignty Case (Philadelphia: New Society Publishers, 1992).

7 Gisday Wa \& Delgam Uukw, The Spirit in the Land: The Opening Statement of the Gitksan and Wet'suwet'en Hereditary Chiefs in the Supreme Court of British Columbia (Gabriola, B.C.: Reflections, 1989).

- Gisday Wa, "Foreword" in A. Mills, ed., Eagle Down is Our Law: Witsuwit'en Law, Feasts, and Land Claims (Vancouver, University of British Columbia Press, 1994); Mas Gak, "Foreword" in A. Mills, ed., Eagle Down is Our Law: Witsuwit'en Law, Feasts, and Land Claims (Vancouver, University of British Columbia Press, 1994); Medig'm Gyamk in F. Cassidy, ed., Aboriginal Title in B.C.: Delgamuukw v. the Queen (Lantzville, B.C.: Oolichan Books, 1992). 
Canadian lawyers and judges) reflects an unmindfulness of another system of law. The Chiefly name of the head of a House group, when appropriately used (properly uttered), connotes an acceptance on the part of the speaker that the person so addressed is the rightful head of a recognized, organized social group. This group is corporate, and extends through an oral history that is marked by song, stories, and witness, and is acknowledged through the remembrance and mindful pronouncement of that same name by others.

An assumption that can generally be made by interlocutors ostensibly speaking in the same language, is that there is an at least partially shared understanding of the social meaning of a term negotiated between speaker and addressee. As, in the example given above:

- the utterance of a name, "Delgamuukw";

- the idea, held by the speaker, of what that name refers to (in the terminology of linguistics, what the direct referent of the term is);

- the hearer's understanding of what the direct referent of the term is;

- and, between speaker and addressee, a negotiation of the social meaning, and social consequences, of the utterance of that name "Delgamuukw," in a particular context.

The lack of a shared understanding on the part of litigants of the social meaning of terms, and even of the nature of their direct referents, underpins the fundamental problem of interpretation that judges are faced with every day. Each case in the areas of Treaty Rights and Aboriginal Rights requires an investigation of understandings (or assumptions of understandings) between individuals of different cultural and linguistic backgrounds,? extrapolated across the sands of time. Judges, I find, are well aware of the difficulties they face, and strive to educate themselves. Some of the very finest professional interpreters of cultural, temporal, and linguistic difference are regularly brought before them, as expert witnesses, to assist them in their task of interpretation.

To divorce the chiefly name from its appropriate use is not unlike what Chief Justice Lamer proposes in the Delgamuukw case. Lamer C.J.C. informs us that such key features of oral histories as "moral obligations" are "tangential to the ultimate purpose of the factfinding process at trial - the determination of the historical truth." ${ }^{10}$ Here, the separation of the chiefly name from its appropriate context provides a term of reference, a "fact," that is not coupled with an acknowledgement of the moral obligation with which it is usually encumbered. The allowance for, and the acknowledgement of, other systems

- The discussion in this ruling has implications for the growing body of anthropological theory and research on "responsibility and evidence in oral discourse," which examines the linguistic means by which a speaker can make a claim, and indicate the source of authority for that claim. See, for example, J. Hill \& J. Irvine, Responsibility and Evidence in Oral Discourse. (Cambridge: Cambridge University Press, 1993). 
of law in which oral histories play a central role, is a theme to which I shall return several times in this paper.

\section{B. How Oral histories are to be Weighted}

Even where the Court seems to demonstrate some understanding of the Gitksan and Wet'suwet'en uses of oral history, it is the occupancy of the land (and its associated built structures), and not the perspectives of the people, that is most heavily weighted. For example, in his summary statement, Lamer C.J.C. explains that oral histories include the performance of Gitksan adaawk and Wet'suwet'en kungax, as follows:

In addition, the Gitksan houses have an "adaawk" which is a collection of sacred oral tradition about their ancestors, histories and territories. The Wet'suwet'en each have a "kungax" which is a spiritual song or dance or performance which ties them to their land. Both of these were entered as evidence on behalf of the appellants....

The most significant evidence of spiritual connection between the Houses and their territory was a feast hall where the Gitksan and Wet'suwet'en people tell and re-tell their stories and identify their territories to remind themselves of the sacred connection that they have with their lands."

I understand, from the emphasized segment above, that it is the feast hall (a building) and not the stories told therein, that contributed the most to his understanding of the connection and claims of the Gitksan and Wet'suwet'en Houses to their lands.

The majority of the Supreme Court of Canada, albeit using the passive voice and not directly naming McEachern C.J., advises in its summary that the court is justified in intervening in such a case: "[A]ppellate intervention is ... warranted by the failure of a trial court to appreciate the evidentiary difficulties inherent in adjudicating aboriginal claims when, first, applying the rules of evidence and, second, interpreting the evidence before it." 12

How does the Supreme Court of Canada suggest "evidentiary difficulties" be approached and interpreted? The Court found that " $[t]$ he trial judge gave no independent weight to these special oral histories."13 An examination of the facts as stated in the body of the judgment reveals that

At the British Columbia Supreme Court, McEachern C.J. heard 374 days of evidence and argument. Some of that evidence was not in a form which is familiar to common law courts, including oral histories and legends. Another significant part was the evidence of experts in genealogy, linguistics, archeology, anthropology, and geography. ${ }^{14}$ 
In Van der Peet, also written by Lamer C.J.C., he argues that "[t]he courts must not undervalue the evidence presented by aboriginal claimants simply because that evidence does not conform precisely with the evidentiary standards that would be applied in, for example, a private law torts case."15 Citing Van der Peet, Lamer, C.J.C. asserts that to reconcile the differences in perspectives presented by common law and law as claimed through oral history: "[t]rue reconciliation will, equally, place weight on each." 16

There we have instructions from the Supreme Court of Canada. But how can such different things be equally weighted? Lamer C.J.C. states that courts must

...adapt the laws of evidence so that the aboriginal perspective on their practices, customs and traditions and on their relationship with the land, are given due weight by the courts. In practical terms, this requires the courts to come to terms with the oral histories of aboriginal societies, which, for many aboriginal nations, are the only record of their past."

Lamer C.J.C. wishes to "come to terms" with the oral histories, but undermines his own point, in part, with the following:

...given that many aboriginal societies did not keep written records at the time of contact or sovereignty, it would be exceedingly difficult for them to produce (at para. 62) "conclusive evidence from pre-contact times about the practices, customs and traditions of their community"."

This is not in any way a "coming to terms" with oral history. One of the fundamental features of oral histories, as recognized in the feast hall, is that it is acknowledged by the participants as providing an authoritative record of past events. I would also argue that it would be exceedingly difficult to produce what could be deemed to be "conclusive evidence" about their "practices, customs and traditions" if courts do not seriously consider oral testimony. In feast halls, shared understandings of territorial boundaries are negotiated, and the reasons for association of Houses with particular territories are restated. I think that Lamer C.J.C. does not recognize the ways in which such oral records are relied upon, and so he resorts to a lesser standard of proof than oral histories can provide. Therefore, the following "proof" is on its own troublesome, and seems to undermine any consideration of the potential reliability of oral histories presented in the feast halls to witnesses:

Conclusive evidence of pre-sovereignty occupation may be difficult to come by. Instead, an aboriginal community may provide evidence of present occupation as proof of pre-sovereignty occupation in support of a claim to aboriginal title. ${ }^{19}$

is Van der Peet, supra note 2 at para. 68, as cited in the Delgamuukw case, supra note I at para. 80 [emphasis removed].

16 The Delgamuukw case, supra note 1 at para. 81, citing Van der Peet, supra note 2 at para. 50. The Delgamuukw case, ibid. at para 84.

Ibid. at para. 83.

Ibid. at para. 152. 
Lamer C.J.C. is not providing guidance as to how to give oral history testimonial weight. Although in the Van der Peet decision he asserts that "[c]ourts must take into account the perspectives of the aboriginal peoples themselves," condition in his decision in the Delgamuukw case which states that it is unnecessary to give evidence that derives from oral history. His emphasis is on adapting the rules of evidence by accepting a different kind of evidence. Rather than considering the substance of the presented oral history - that is, the oral documents that are told from "the perspectives of the aboriginal people themselves" - he has "pre-sovereignty occupation" stand as a proxy. Lamer C.J.C's instructions to follow the principles laid down in the Van der Peet decision simply do not allow for an interpretation beyond that which can be afforded to a text in which the social meanings and direct referents of all terms are evident to the judge, or, at least, can be made evident through written (Euro-Canadian) records of the times in question.

\section{ON HEARSAY: MCEACHERN C.J.'S ATTEMPT TO ADMIT ORAL History AS TESTIMONY}

Three weeks into his hearing of the Delgamuukw case, McEachern C.J. ruled on the admissibility of oral history in that case. According to a recognized exception that declarations by deceased persons can be given in evidence by witnesses as proof of public or general rights, McEachern C.J. ruled oral history admissible, as an exception to the hearsay rule. ${ }^{21}$ Therefore, when witnesses recount their ancestors' declarations, this provides an account that is admissible as proof of general rights. The Supreme Court of Canada concurred with McEachern C.J.'s ruling.

All looked promising for the serious consideration of oral history, but McEachern C.J. also said at that time that he would determine the admissibility of some of the evidence later: "[N]ot all of the [oral history] evidence would be admissible, but questionable evidence would be received subject to a later determination of admissibility." ${ }^{22} \mathrm{He}$ gave as a partial reason that both Mr. Jackson, for the plaintiffs, and Mr. Goldie, for the Crown, thought that "extensive anthropological and other testimony, which he had not yet heard, would help him with this interpretation." ${ }^{23}$ McEachern C.J. then heard the anthropological evidence, which included a contextualization of the oral history narratives.

Lamer C.J.C. discussed McEachern C.J.'s interpretation of the anthropologists' testimony in his judgment:

One objection that I would like to mention specifically, albeit in passing, is the trial judge's refusal to accept the testimony of two anthropologists who were brought in as expert witnesses by the appellants. This aspect of the trial judge's reasons was hotly contested by the appellants in their written submissions. However, I need only reiterate what I have stated above, that findings of credibility, including the

20 Van der Peel, supra note 2 at para. 48 [emphasis added].

21 Uukw v. R., [1987] 6 W.W.R. 156.

$22 \quad$ Ibid. at 156.

23 Ibid. at 163. 
credibility of expert witnesses, are for the trial judge to make, and should warrant considerable deference from appellate courts. ${ }^{24}$

This could mean that if oral histories are not placed in context for the trial judge by people other than the expert witnesses, they may be disregarded, as the judge may find that he does not have the tools to evaluate them.

\section{The Role of ANThropologists: The Place of Judicial Notice ${ }^{25}$}

Trial judges are still able to dismiss oral histories on the ground that they have not been made intelligible to participants in a Euro-Canadian judicial system. In taking judicial notice, judges are able to consider that "the matter need only be common knowledge in the particular community in which the judge is sitting."26 The holding of sessions on Indian reserves can shift the available store of "common knowledge," but that common knowledge might not at first be recognizable to a judge newly visiting a community. $\mathrm{He}$ or she might be occupied with extra work in hours that would otherwise allow acquaintance, through socialization, with what locally, "everyone knows." 27 To expand the judicial notice of the judges who make decisions in the Canadian courts, we must begin to expand their exposure to alternative perspectives on the world earlier in their lives.

If we are to expect oral histories of Aboriginal Peoples to be given more consideration in Canadian courts, we must develop our educational system in such a way that it becomes unreasonable for a trial judge to be unaware of the workings of such orally-based legal traditions. We must encourage public schools to make use of textbooks and other curricular materials that foster an understanding of alternative legal histories on their own terms. These textbooks include, most notably, Olive Dickason's eminently readable history text, Canada's First Nations, ${ }^{28}$ and the Yukon social studies textbook, Reading Voices: Oral and Written Interpretations of the Yukon's Past, written by Julie Cruikshank. ${ }^{29}$ Both of these texts make the perspectives of non-Euro-Canadians accessible to high school students, and are based on ethno-historical and anthropological research of highly-regarded

The Delgamuukw case, supra note 1 at para. 91.

Judicial notice is the term used to describe the practice of the courts using their knowledge about the world to make decisions without requiring the parties of the action to prove the things known by the court. "Judicial notice is the acceptance by a court or judicial tribunal, in a civil or criminal proceeding, without the requirement of proof, of the truth of a particular fact or state of affairs. Facts which are (a) so notorious as not to be the subject of dispute among reasonable persons, or (b) capable of immediate and accurate demonstration by resorting to readily accessible sources of indisputable accuracy, may be noticed by the court without proof of them by any party": J. Sopinka, S.N. Lederman \& A.W. Bryant, The Law of Evidence in Canada, 2d ed. (Toronto: Butterworths, 1999) at 1055, sec. 19.13 [hereinafter The Law of Evidence in Canada]. McLeod, supra note 4, has a discussion of judicial notice which demonstrated to me the importance of considering the place of judicial notice in the development of new interpretations of law.

The Law of Evidence in Canada, ibid. at 1055, sec. 19.14, quoting then-Chief Justice Duff. Ibid.

Canada's First Nations: A History of Founding Peoples. (Toronto: McClelland and Stewart, 1991). Dàn Dhá Ts'edeninth'é / Reading voices: Oral and Written Interpretations of the Yukon's Past (Vancouver: Douglas and McIntyre, 1991). 
scholars. In order to give potential future members of the Canadian judiciary time to consider and develop their opinions on such matters, we must ensure that, at the very least, everyone develops an early awareness of the controversies within our legal system. To foster such an awareness, we must also rectify the recent excisions of the mention of Aboriginal Peoples and their systems of governance and social organizations from some newer editions of high school textbooks now in circulation in Canada. This avoidance of controversy in print through social erasure has been cogently documented by Elizabeth Furniss. ${ }^{30}$ Anthropologists, including this author, must also be able to publish in places that judges and their clerks are likely to look. The work of a few anthropologists could make further significant contributions to the reading lists of sitting judges, and their clerks. We must, as Ridington has advised, attend to the "conflicting models of discourse," ${ }^{31}$ and explicitly identify those instances in which such conflicts might preclude an understanding, on the part of judges, of the unfamiliar social meanings clothed in terminology that seems, at first glance, to reflect a common understanding of terms in use.

\section{CONTRAsting Notions OF TItLe AND SOVEREIGNTY: DIFFERENT WORLDVIEWS}

In their opening address to the Supreme Court of British Columbia, the Gitksan and Wet'suwet'en hereditary Chiefs Gisday Wa and Delgam Uukw ${ }^{32}$ asked that their title be recognized (this was not qualified as aboriginal title), and that sovereignty of the land be recognized (not the sovereignty over the land of any party, whether Crown, Gitksan, or Wet'suwet'en). ${ }^{33}$ This is in keeping with the hereditary chiefs' discussion in The Spirit in the Land, in which they assert their rights of "ownership and jurisdiction." 34 The Supreme Court of Canada failed to address the request. Instead, it addressed the issue of

The Burden of History: Colonialism and the Frontier Myth in a Rural Canadian Community (Vancouver: University of British Columbia Press. 1999).

R. Ridington, "Cultures in Conflict: The Problem of Discourse" in Little Bit Know Something: Stories in a Language of Anthropology (lowa City: University of lowa Press, 1990) at 189. See also "Fieldwork in Courtroom 53: A Witness to Delgamuukw v. B.C." 95(2) B.C. Studies Special Issue 12. We can find some guidance in the detailed critiques of McEachern C.J.'s reasons put forward by a number of scholars in anthropology, history, the law, and in the Gitksan and Wet'suwet'en communities. In particular, 1 refer to: B.C. Studies Special Issue 95(2), B. Miller, ed.; the session, Anthropologists On Stage and Back Stage: Expert Witnessing in First Nation Litigation. This was presented at the 22nd Annual Meeting of the Canadian Anthropological Society (CASCA), Learned Societies Conference, Université du Québec à Montréal, May 1995. Papers by Dara Culhane, Antonia Mills, Robert Paine, Bruce Miller, John Cove, James McDonald and Tom Weegar, Andie Palmer, Adrian Tanner, and Joan Ryan, and organized by Bruce Miller, with discussion by Randy Kandel and John Borrows.

Each of these names can be spelled several ways. The Nass-Gitksan language is now written, but, as with English, the standardization of orthographic representation, the spelling of names, and the education of publishers as to what constitute word boundaries (as opposed to morpheme boundaries), takes some number of years to work out. 
"occupancy and possession." 35 This is not merely a limitation due to legal language, but also of the associated legal view, which is that the Crown holds underlying title. A consideration of what sovereignty of land might mean to Gisday Wa and Delgam Uukw and members of their Houses needs to be unbound from the context of a decision made within the Canadian court system, which, of course, is where matters are to be decided that are considered to be under that court's jurisdiction. Judgments by the Supreme Court of Canada are made entirely within the context of an assumption that the Crown has the underlying title to all land, rather than in the context of an assumption of a nation-tonation relationship, where different systems of law (and different understandings of what constitutes a person or spirit) might be treated as commensurate. The Supreme Court of Canada has not made use of an examination of relationships between the concerned parties, the Crown and the Wilip (or Houses), at the time in history where common law and aboriginal law converged. Nor has the Court found it necessary to consider whether an assertion of sovereignty by the Crown, at that shared point in history, meant anything at all under another system of law. As such, an explanation that, for Delgamuukw and the members of his House, "the ownership of territory is a marriage of the Chief and the land," ${ }^{36}$ has not been accommodated by the Canadian courts.

\section{THE LARGER ISSUE}

I am concerned that by attending to the minute details of this discussion I will loose sight of the larger issues, and by engaging in arguments framed within the system, I am complicit with it. At first, I did not think that this would be the case, but the larger issue, that of facilitating two cultures' communication, has been framed within the context of a colonialist court throughout most of this paper. However, as Medig'm Gyamk [Neil Sterrit] points out in the title of his essay, "It doesn't matter what the judge said,"37 the court case "was only one of the ways we [the Gitksan and Wet'suwet'en] sought to achieve justice within our territories." ${ }^{" 38}$ And truth, as he defines it, is in the following:

The elders ... went in and they said how they felt, what they knew about the land, what they wanted in the future, and where they came from in the past. It was that truth, ultimately, that will be important.... [B]ecause it is all written. It is all there."

The Delgamuukw case, supra note 1, per La Forest J. and L'Heureux-Dube' J. at para. 188, Lamer C.J.C. on occupancy at paras. 144-47. I found Hamar Foster's discussion of what he views as McEachern C.J.'s confusion between rights and title very helpful in the formulation of this point (see H. Foster, "It goes Without Saying: Precedent and the Doctrine of Extinguishment by Implication in Delgamuukw v. The Queen" (May 1991) 49 Advocate 341).

Gisday Wa \& Delgam Uukw, supra note 7 at 7 . The notion of land as a non-human person, as one imbued with a spirit, that is, as one with whom a hereditary chief would enter into a relationship based on respect, and with an expectation of mutual responsibility, provides a basis for what is deemed to be proper behaviour under Gitksan law.

"It Doesn't Matter What the Judge Said" in F. Cassidy, ed., Aboriginal title in British Columbia: Delgamuukw v. The Queen, Proceedings of a conference held September 10-11, 1991 (Lantzville, B.C.: Oolichan Books and The Institute for Research on Public Policy, 1992) at 303. Ibid. at 305. 
Even though the Canadian judicial system makes use of a set of laws, set out in a language that is not entirely shared by Medig'm Gyamk, his wearing of that chiefly name, and the understanding of the laws by which he can claim it on the part of those who utter it in its appropriate context, is indicative of the enduring relevance of a body of law beyond the control of the Canadian courts. Perhaps, in the study of law in Canada, we should become increasingly mindful of accounts situated within legal frameworks which have origins independent of the common law tradition developed under the influence of a lineage of British sovereigns that has extended into Canadian courts. 